\title{
India and the Indian Ocean region
}

\author{
Sangeeta Khorana ${ }^{a}$ and Leïla Choukroune ${ }^{b}$
}

${ }^{a}$ Bournemouth University, Business School, Bournemouth, UK; ${ }^{b}$ Centre for Sciences and Humanities, New Delhi, Indią

\section{Introduction}

International relations are in a state of dynamic transition, with the emergence of an assertive China, growing India and the United States (US) as main players in the Indian Ocean region (IOR). China's growing geopolitical influence (developed in the so-called String of Pearls theory) and assertiveness in the South China Seas, complemented by the US policy aimed at enhancing operational integration in the region has led India to realign and outline its strategic vision under Prime Minister Narendra Modi to play a significant role in the IOR. This Special Issue of JIOR fleshes out this theme and other related topical issues in the region, focussing in particular on the growing interplay between China, India and the US - the three pillars - that play an increasingly important role in the reconfiguration of geopolitics in the IOR.

The evolving strategic importance of India Ocean $(\mathrm{IO})$ has been in focus recently when, on 12 July 2016, Beijing's territorial ambitions in the South China Sea suffered a major blow as a result of a landmark decision of the Hague Permanent Court of the Arbitration in favour of the Philippines. The relevance of this decision is resounding in that the IOR is a highly strategic waterway rich in fishery resources, and potentially oil and other energies, which makes it among one of the most coveted in the world with no less than six coastal states (Brunei, China, Malaysia, the Philippines, Taiwan and Vietnam) having made competing claims on the Spratly Islands. Beijing, however, remains the main actor of this conflict since it claims sovereignty over all the islands, islets, rocks, sand banks or shoals dispersed in an area bounded by a famous U-shape curve that is deemed to include ipso facto, and ab initio, the 'natural prolongation' of the country.

The strategic importance of the region can be traced to when China signed the United Nations Convention on the Law of the Sea (UNCLOS), and adopted at Montego Bay on 10 December 1982 after nine years of negotiations, and ratified in 1996 two years after its entry into force. The Declaration made by Beijing at the time of ratification is not without interest and states that

the People's Republic of China (PRC) reaffirms its sovereignty over all archipelagos and islands listed in Article 2 of the law of the People's Republic of China on the territorial sea and the contiguous Zone which was promulgated on 25 February 1992.

It is evident that it is impossible for Beijing to forfeit the claims on the basis of its conception of international law and its relation to the domestic law of the PRC. From this absolutist and uncompromising vision of state sovereignty derives an extensive conception of

CONTACT Sangeeta Khorana skhorana@bournemouth.ac.uk, sangeetakhorana@hotmail.co.uk 
rights that could benefit China in the name of an international law that it accepts as reinterpreted in favour of a beneficial application of the Montego Bay definitions of archipelagic waters, territorial sea or exclusive economic zone. Long opposed to a judicial settlement, Beijing did not accept the jurisdiction of the Hague Permanent Arbitration Court, did not participate to the proceeding and eventually denounced its unfavourable unanimous award as a 'farce' and a 'null and void' decision. However, 'the Tribunal found that it has jurisdiction to consider the Parties' dispute concerning historic rights and the source of maritime entitlements in the South China Sea' and concluded that 'to the extent China had historic rights to resources in the waters of the South China Sea, such rights were extinguished to the extent they were incompatible with the exclusive economic zones provided for in the Convention'. In short, 'there was no legal basis for China to claim historic rights to resources within the sea areas falling within the "ninedash line"' (The Guardian, 2016).

No matter what could be commented on the legality and legitimacy of such arbitral decisions taking primacy over permanent dispute settlement bodies and the law of the sea tribunal in particular, the controversial yet historic award enjoys the merit of putting international law in a rather tensed and unbalanced environment. Other regional players were prompt to react. For instance, India's reaction can be measured with the Ministry of External Affairs issuing a statement affirming its 'utmost respect' for the UNCLOS and restating that 'India supports freedom of navigation and over flight, and unimpeded commerce, based on the principles of international law, as reflected notably in the UNCLOS.' In addition 'India believes that States should resolve disputes through peaceful means without threat or use of force and exercise self-restraint in the conduct of activities that could complicate or escalate disputes affecting peace and stability' (Indian Express, 2016).

This non-aggressive yet assertive posture is representative of a new Indian geostrategic policy, which, as we see in this Special Issue, has triggered a series of strategic responses in anticipation of India's regional counterparts and competitors' maritime ambitions in the IO region. In terms of international trade, $90 \%$ of Indian trade by volume and $90 \%$ of oil imports take place through the sea, which explains the underlying rationale behind the growing importance of IOR in New Delhi's strategic plans expressed in the 2015 Bhubhaneshwar Declaration at a conference hosted by research and information system for developing countries. It was reiterated in the Declaration and as a regional power India views the IOR as its theatre of influence. Since Narendra Modi became prime minister, maritime security, focused on the Indian Ocean, has become a top priority in India's domestic and foreign security policy given that the IOR is responsible for two-thirds of world's oil shipment, one-third of world's cargo movement and nearly half of container traffic movement (The Hindu, 2015). The realignment in focus is in line with India's efforts to assert its position as a global power and net security provider in its neighbourhood and beyond, at a time when most sources of tension and potential conflict in Asia lie at sea. The changing focus is also driven by China demonstrating its growing geopolitical influence in the form of accessing ports and airfields, expanding and modernising military forces, fostering stronger diplomatic relationships with trading partners, commonly termed the 'String of Pearls' theory, and an assertive policy agenda in the South China Seas. The US too is enhancing operational integration in the IOR, mainly through military deployment and strengthening its military alliance with Japan. Within this context, the IOR occupies a central position in 
India's strategic landscape, and the growing geostrategic and geo-economic salience of the IOR reiterates the need to address and confront non-traditional security threats, some of which include energy, maritime terrorism and piracy; trans-national crimes; and environmental and natural disasters. This special issue proposes to investigate the topical theme of the positioning of 'new global India' in a non-directly confrontational manner against China, the United States of America and other regional leaders.

We have assembled a collection of five articles that address some of the topical questions important from the perspective of India. The structure and content of this special issue is strongly influenced by India's growing role and involvement in the IOR, and its shifting foreign policy stance under the Modi government. Although each of the following articles stand solidly on their own merits, we have made an effort to impose a rough thematic structure and logical flow in their ordering, motivated by an interest in emphasising some of the evolving issues in the IOR.

The first article of the special issue is a historical and country-based analysis, and Smruti S. Pattanaik reviews India's relations with its neighbours, in particular China. In doing so, the author examines the evolution of India's approach to its geostrategic policy in the IOR within the backdrop of China's growing presence in the region. The paper eloquently sums up India's policies towards its maritime neighbours, the response of these countries to India's strategies and eventually dares to gaze into the crystal glass to comment on what the future holds for India in the emerging geopolitical context.

Looking at China, Anasua Basu Ray Chaudhury and Pratnashree Basu address the challenges of cooperation as an alternative and more sustainable path to generate synergies in the IOR. The authors look at the growing importance of the Bay of Bengal as a reservoir of vital resources for countries in the region and how this impacts the ability of India and China, the main players, to exert influence in light of their dependence on oil. The article highlights that the dynamic South China Sea could possibly impact on India's interests and relations with the Southeast Asian countries, and suggests possible strategies for greater cooperation in the region.

Using the India-United States-China framework, Antara Ghosal Singh discusses the geopolitical developments in the Indo-Pacific region. The contribution employs the constructivist approach in international relations and sheds light on a possible 'ménage à trois' in which the US is keen to play a greater role in the region.

In reviewing the 'Act East' policy Isabelle St Mezard gauges New Delhi's abilities to respond to China's Maritime silk road initiative and its transformation into a security provider. The contribution discusses how India's 'Look East' policy is being transformed into 'Act East' policy that is complemented with India's role as a security provider and growing involvement in the Bay of Bengal.

P.K. Ghosh uses the case study of the Indian navy as an actor to facilitate the implementation of India's foreign policy objectives. This paper uses a holistic maritime security cooperation and capacity-building approach. In doing so, the contribution presents an insight into the growing role of the Indian navy to counter Chinese presence in the region. The contribution highlights how the Indian navy has successfully conducted regular joint exercises, conducted port visits and coordinated patrols as a means for capacity building in the region.

To conclude, the special issue of Journal of Indian Ocean Region explores issues of relevance to the dynamic and evolving IOR and analyses the discourse from the practitioner 
and academic perspectives. It highlights the complexity of geopolitical strategy in light of growing role of India, China and US in the region. The main strength of the articles in the special issue is their first-hand informative analysis of what the changing dynamics will imply for the region. The special issue is topical in that it comments on the perception of IOR from an Indian lens in a volatile region, when South China Seas is debated and Japan is playing a growing role. The compilation of contributions thus marks the beginning of our journey in analysing the paradigms of evolving geopolitical issues from the perspective of India, a growing power with definite interests in the region.

\section{Disclosure statement}

No potential conflict of interest was reported by the authors.

\section{References}

Bhubhaneshwar Declaration. (2015). Conference on Indian Ocean: Renewing the maritime trade and civilisational linkage. Retrieved August 6, 2016, from http://ris.org.in/pdf/Bhubaneswar\% 20Declaration.pdf

The Guardian. (2016, July 12). Beijing rejects tribunal's ruling in South China Sea case.

The Hindu. (2015, March 17). Mr. Modi's ocean view. Retrieved August 6, 2016, from https://www. theguardian.com/world/2016/jul/12/philippines-wins-south-china-sea-case-against-china

Indian Express. (2016, July 14). China gives guarded reaction to India's South China Sea statement. Retrieved August 6, 2016, from http://indianexpress.com/article/india/india-news-india/chinagives-guarded-reaction-to-indias-south-china-sea-statement-2911128/ 